\title{
TAFSIR AL-QUR'AN DENGAN AL-SUNNAH
}

\author{
Isa Ansori \\ IAIN Jurai Siwo Metro \\ ansoriok@gmail.com
}

\begin{abstract}
This paper focuses on describing the interpretation of al-Qur'an with alSunnah. The use of sunnah or hadith for the interpretation of the Qur'an can be seen from several aspects, from the aspect of the assessment of the contents of the texts, it is distinguished into, first, using the sunnah or hadith which its contents directly affects the Qur'an, or second, using the sunnah or hadiths that are useful for supporting interpretation although the content of the texts has no direct relation to lafaz or verse being interpreted. In addition, the sunnah or hadith also can be seen from its function in explaining lafaz or verse, explaining topics such as figh, tasawuf, history etc., explaining etymology, snatching, asbäb al-nuzul support, and other uses that may be found along with the development of science. While in the study of Islamic jurisprudence, the position of sunna against the Qur'an has an important function as bayān al-taqrīr, bayān al-tafsìr which includes tafșil al-mujmāl, takhșiṣ al-'àm, taqyid al-muṭlaq, also bāyan al-tashrī', bàyan al-nasakh and defines the mubham.
\end{abstract}

Keywords:Tafsir, al-Qur'an, al-Sunnah

\section{Abstrak}

Artikel ini fokus mendeskripsikan tentang penafsiranal-Qur'an dengan al-Sunnah (hadis). Penggunaan sunnah atau hadis untuk penafsiran alQur'an dapat dilihat dari beberapa aspek, dari aspek penilaian isi nash 
yang dibedakan menjadi, pertama, menggunakan sunnah atau hadis yang isi nashnya secara langsung menafsirkan al-Qur'an, atau kedua, menggunakan sunnah atau hadis yang berguna untuk mendukung penafsiran meskipun isi nash tidak mempunyai hubungan langsung dengan lafaz atau ayat yang sedang ditafsirkan.Selain itu, sunnah atau hadis dapat dilihat dari fungsinya yaitu untuk menjelaskan lafaz atau ayat, menjelaskan topik seperti fiqih, tasawuf, sejarah dsb., menjelaskan etimologi, menakwil, dukungan asbābal-nuzul, dan kegunaan-kegunaan lain yang mungkin saja akan diketemukan seiring dengan perkembangan ilmu pengetahu-an. Sedang dalam kajian fikih, kedudukan sunnah terhadap al-Qur'andipandang memiliki fungsi penting sebagai bayānal-taqrīr, bayānal-tafsīryang mencakup tafṣilalmujmāl, takhṣiṣal-ām, taqyidal-muṭlaq, juga bāyan al-tashrī’ bāyan alnasakh dan mendefinisikan yang mubham.

Kata Kunci: Tafsir, al-Qur'an, al-Sunnah

\section{A. Pendahuluan}

Menafsirkan al-Qur'an dengan al-Sunnah adalah salah satu cara penafsiran yang biasa digunakan dalam metode tafsir bi al-Ma ${ }^{\dot{s}} \bar{u} r$. Tafsir bial-Ma'sūr adalah salah satu metode penafsiran al-Qur'an yang paling kuat dan diakui keabsahannya, yaitu metode menafsirkan nashnash al-Qur'an dengan menggunakan nash-nash al-Qur'an itu sendiri atau menggunakan sunnah Rasulullah SAW. Pada saat al-Qur'an diturunkan, Rasulullah SAW sebagai penerima wahyu adalah satusatunya orang yang paling memahami wahyu yang beliau terima dari Allah sebagai DzatPemberi wahyu.Karenanya, menafsirkan Al-Qur'an menggunakan sunnah diyakini sebagai salah satu metode memahami wahyu agar sesuai dengan maksud yang dikehendaki oleh Dzat Pemberi wahyu.

Khalid Abdul Al-Rahman Al-Ak mengutip Al-Syatibi menerangkan bahwa pengertian al-Qur'an jika dikaitkan dengan hukum-hukum syariah kebanyakan mengandung makna kulliy (global) bukan juziy(rinci), dan meskipun juziy maka harus diambil kulliy dengan cara menggunakan penjelasan-penjelasan, atau mengikuti makna asal, kecuali jika ditakhsis dengan dalil, seperti ditakhsis 
dengan Sunnah. ${ }^{1}$ Ini menunjukkan bahwa Al-Qur'an memerlukan banyak penjelasan, dan fungsi Sunnah adalah menjelaskan Al-Qur'an. Tentusaja tidak terbatas permasalahan hukum, namun mencakup seluruh persoalan kehidupan manusia.

Tulisan ini berupaya mendeskripsikan lebih lanjutan tentang penafsiran al-Qur'an dengan al-Sunnah.Pembahasan dalam tulisan ini mencakup pengertian, keterkaitan tafsir dan sunnah, fungsi sunnah dalam penafsiran al-Qur'an, metode dan model penafsiran sunnah terhadap al-Qur'an.

\section{B. Tafsir dan al-Sunnah}

Dari segi bahasa tafsir bermakna menampakkan dan menjelaskan, ${ }^{2}$ makna seperti ini juga digunakan Surah al-Furqon ayat 33 "walāya'tūna kabima salinil lāji'nā kabi al-haqqi wa ahsana tafsìrā." Maksud kata tafsir pada ayat ini adalah memberikan penjelasan dan rincian. Kata tafsir diambil dari kata "al-fassara" yang bermakna menampakkan dan membuka. Secara bahasa kata ini digunakan dalam makna membuka al-hissi(berhubungan dengan perasaan), dan membuka makna-makna yang dapat dinalar (masuk akal) ${ }^{3}$. Sedangkan menurut syara' tafsir adalah menjelaskan makna ayatmengenai arti pentingnya, kisahnya, sebab diturunkannya, menggunakan lafaz yang dapat menunjukkan maksud yang merupakan fakta. ${ }^{4}$

Dari pengertia di atas, dapat dipahami bahwa menafsirkan ayat Al-Qur'an adalah upaya membuka atau menampakkan makna yang dapat dirasakan dan dinalar menggunakan penjelasan secara lafẓi yang dapat menunjukkan maksud yang merupakan fakta dari suatu ayat. Ini adalah suatu upaya menggali maksud yang sebenarnya dari pembuat syariat, yaitu Allah SWT. Sehingga maksud itu dapat diaplikasikan dan direalisasikan oleh setiap hamba-Nya dalam kehidupan sehari-sehari

${ }^{1}$ Khalid Abdul al-Rahman al-Ak, Ușūl al-Tafsīr wa Qawā'iduhu, (Beirut: Dar Al-Nakhais, 1986), h. 126.

${ }^{2}$ Muhammad Husain al-Dzahabi, Al-Tafsìr wa al-Mufassirūn, Jil. 1, (Kuwait: Dar al-Nawadar, 2010), h. 13.

${ }^{3}$ Khalid Abdul Rahman al-Ak, Ușūl al-Tafsir... h. 30.

${ }^{4}$ Ibid.,h. 30. 
dalam rangka beribadah menggapai keridhaan-Nya dan memperoleh kebahagiaan hidup di dunia hingga akhirat.

Sedangkan al-Sunnah secara bahasa berarti jalan, baik terpuji atau tercela. ${ }^{5}$ Sunnah dalam pengertian ini digunakan seperti dalam hadis Nabi SAW yang diriwayatkan oleh Syaikhani: "Rasulullah SAW bersabda: "Barangsiapa yang merintis suatu jalan dalam Islam dengan jalan yang baik, maka ia akan mendapatkan pahalanya dan pahala orang mengamalkannya sesudahnya tanpa berkurang sedikitpun dari pahalanya, dan barangsiapa merintis jalan dalam Islam dengan jalan yang jelek, maka ia mendapatkan dosanya dan dosa orang yang mengamalkannya sesudahnya tanpa berkurang sedikitpun dari dosanya".

Menurut istilah ahli hadis, sunnah adalah apa yang ditinggalkan dari Nabi SAW ( $\dot{a} s \bar{a} r$ ) berupa ucapan, perbuatan, taqrir, sifat fisik atau akhlak, atau sirah (peri kehidupan), baik sebelum beliau diangkat menjadi Rasul atau sesudahnya. ${ }^{6}$ Menurut istilah ahli ushulfiqh, Sunnah adalah apa yang dinukil dari Nabi SAW baik berupa ucapan, perbuatan atau takrir. ${ }^{7}$ Sedangkan menurut istilah ahli fiqih, sunnah adalah apa yang ditetapkan dari Nabi SAW tanpa pewajiban, penerimaan wajib dan yang lainnya dari hukum yang lima (wajib, Sunnah, mubah, makruh, haram), termasuk apa yang disebut dengan bid'ah. ${ }^{8}$

Perbedaan ulama dalam mendefinisikan sunnah adalah dipengaruhi dari tujuan mereka menggunakan sunnah, tergantung latar belakang keilmuan yang mereka tekuni. Ulama hadis dalam bahasannya menetapkan Rasul SAW sebagai imam yang memberikan petunjuk, yang oleh Allah disebut sebagai uswah hasanah, karenanya, mereka menukil apa saja yang terkait sirah (perilaku kehidupan), sifat fisik dan akhlak, berita, ucapan, perbuatan, baik yang dapat ditetapkan sebagai hukum syara' maupun yang tidak. Ulama ushulfiqh, membahas Rasulullah SAW sebagai yang menetapkan syariat dan

5 Mustafa al-Siba'i, Al-Sunnah waMakānatihāfĩ al-Tasyri' al-Islāmi, (Kairo: Maktabah Dar al-Urubah, 1961), h. 59.

${ }^{6}$ Ibid., h. 59.

${ }^{7}$ Ibid., h. 59.

${ }^{8}$ Ibid., h. 60. 
meletakkan kaidah-kaidah bagi orang-orang yang berijtihad setelah beliau, dan kedudukan beliau sebagai orang yang menjelaskan dasardasar kehidupan kepada umat manusia, karenanya, mereka mengambil ucapan, perbuatan, atau takrir Nabi yang dapat menjadi ketetapan hukum. Ulama fiqih, mereka membahas Rasulullah SAW berhubungan dengan perbuatan-perbuatan beliau yang dapat dijadikan dalil hukum syara', mereka membahas hukum syara' yang berhubungan dengan perbuatan manusia, baik wajib, haram, mubah dan lain-lain.

Bagi ulama tafsir, membahas Rasul adalah dengan memandang beliau sebagai ahli tafsir yang memahami dan mempraktikkan seluruh al-Qur'an dalam kehidupan beliau.Cakupan bahasan tafsir luas, seluas yang tercakup dalam al-Qur'an. Karenanya, seorang mufasir seharusnya mampu menempatkan Rasul sebagaimana para ahli hadis, ahli ushulfiqh, ahli fiqih, bahkan ahli-ahli ilmu lain, dalam rangka memahami ucapan, perbuatan, dan takrir beliau untuk menafsirkan al-Qur'an.

Selain kata sunnah, sering juga digunakan padanan kata lain yang semakna yaitu "hadis". Definisi hadis, ini juga tidak jauh berbeda dengan sunnah. Secara etimologis kata al-hadisbermakna"baru”, lawan kata al-qadìm(dahulu).Berasaldari akar kata "hadasa - yahdusu

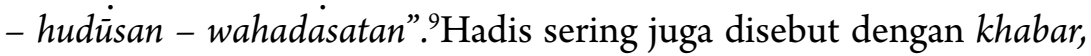
yang bermakna berita, yaitu apa-apa yang datang kepada seseorang tentang suatu berita dari orang yang memberi berita. ${ }^{10} \mathrm{Hadis}$ dengan makna berita juga tersebut dalam Surah al-Ṭur ayat 34, al-Kahfi ayat 6, dan al-Duhā ayat 11.

Sedangkan menurut istilah, para ahli memberikan definisi hadis dengan pengertian yang berbeda-beda, dipengaruhi oleh perbedaan latar belakang bidang keilmuan mereka. Ahli hadis memberikan definisi hadis sebagai"Segala ucapan Nabi SAW, perbuatan dan hal ihwalnya."Yang dimaksud dengan "hal ihwal” ialah segala yang

9 Muhammad bin Mukram bin Manẓural-Afriqial-Misri, Lisānal-Arab, Juz 2, (Beirut: Dar Shadr, t,t.), h. 131.

${ }^{10}$ Ibid., h. 131. 
diriwayatkan dari Nabi SAW yang berkaitan dengan himmah, karakteristik, sejarah kelahiran, dan kebiasaan-kebiasaannya. ${ }^{11}$

Ada juga ahli hadis yang memberikan definisi hadis lebih luas, yang melihat"bahwa hadis itu tidak hanya untuk yang marfu', yaitu yang disandarkan kepada Nabi SAW, melainkan dapat juga yang mauquf, yaitu yang disandarkan kepada para sahabat atau yang maqtu' yaitu yang disandarkan kepada tabi'in". ${ }^{12}$

Sementara Muhammad Jamal al-Din bin Muhammad Sa'id bin Qasim al-Halaq al-Qasimi, dalam bukunya Qawā'id al-Tahdis min FunūniMuștālah al-Hadis, menyamakan pengertian hadis, khabar dan atsar.Ketigakata ini adalah sinonim, dengan pengertian sama yaitu“Segala yang disandarkan kepada Nabi SAW, baik berupa ucapan, perbuatan, taqrir atau sifat." 13

Sedangkan ahli fiqih dari Kharasan membedakan pengertian ini, menyebut hadis yang mauqüf(tidak bersandar langsung kepada Nabi SAW) dengan nama asar,dan hadis yang marfü' (yang disandarkan langsung kepada Nabi SAW) dengan nama khabar. ${ }^{14}$ Adapun ahli ushulfiqh, mendefinisikan hadis dengan "segala ucapan, perbuatan, dan taqrirnya yang berkaitan dengan hukum syara' dan penetapannya.

Dengan demikian, berdasarkan penjelasan definisi sunnah dan hadis di atas, dapat dikatakan bahwa sunnah dan hadis memiliki makna yang sama sebagai ucapan, perbuatan dan taqrir dari Nabi SAW yang dapat digunakan untuk menafsirkan al-Qur'an.

\section{Keterkaitan Tafsir dan Sunnah}

Kata "tafsir" dan "sunnah" memiliki keterkaitan erat. Dari dua kata ini, Musaa’ad bin Sulaiman bin Nashar al-Ṭayar merumuskan

${ }^{11}$ Munzier Suparta, Ilmu Hadis, (Jakarta: Rajawali Pers, 2011), h. 2 mengutip Muhammad Mahfudz ibn Abdillah al-Timisi, Manhaj al-Nazar, (Jeddah: al-Haramain, 1974), h. 8.

${ }^{12}$ Ibid.h. 3

${ }^{13}$ Muhammad Jamal al-Din bin Muhammad Sa'id bin Qasim al-Halaq alQāsimi, Qawā'id al-Tahdis min FunūniMuṣtalah al-Hadis, Juz 1, (Beirut: Dar Al-Kitab Al-Ilmiyyah, t.t.), h. 61 .

${ }^{14}$ Ibid., h. 61 
dua istilah ilmu tafsir yaitu, "tafsir bial-sunnah" (tafsir menggunakan sunnah) dan "tafsir al-nabawiy" (tafsir nabawi).Tafsir nabawi adalah setiap ucapan atau perbuatan yang disandarkan dan bersumber dari Nabi SAW yang secara jelas dimaksudkan sebagai tafsir dari suatu ayat al-Qur'an.Sedangkan tafsir dengan menggunakan sunnah mengandung makna setiap sunnah yang bagi mufasir berfaedah atau berguna untuk menafsirkan al-Qur'an. ${ }^{15}$

Pembedaan menjadi dua istilah ini: tafsìrbial-sunnahdan tafsìralnabawiytidak disepakati oleh Khalid bin 'Abd al-Aziz al-Baatili. Ia lebih senang dua istilah ini disebut dengan satu istilah saja, yaitu Al-TafsiralNabawiy(tasfirnabawi). Ia mengkritik definisi tafsir nabawi yang dirumuskan oleh al-Tayar: pertama, definisi al-Tayar mengecualikan takrirnabawi, yaitu takrir yang bersumber dari dan disandarkan kepada Nabi SAW, padahal takrir semacam ini menurut al-Bātili adalah termasuk tafsir nabawi karena bersumber dari Nabi SAW dan berguna untuk menafsirkan sesuatu dari ayat al-Qur'an. Kedua, definisi al-Tayar, mentaqyidyang "jelas", mafhumnya adalah apa-apa yang datang dari Nabi SAW dan berfaedah untuk menafsirkan al-Qur'an tetapi tidak jelas dimaksudkan sebagai tafsir adalah bukan tafsir nabawi. Menurut al-Bātili, sepantasnya ini dimasukkan sebagai tafsir nabawi karena bersumber dari Nabi SAW dan berfaedah menjelaskan makna alQur'an. Karenanya, al-Bātilimerumuskan definisi ulang tafsir nabawi sebagai apa-apa yang bersumber dari Nabi SAW baik berupa ucapan, perbuatan, atau takrir yang menjelaskan makna-makna al-Qur'an. ${ }^{16}$

Alasan al-Tayar membedakan dua istilah antara tafsir nabawi dengan tafsir menggunakan sunnah, adalah perlunya penggunaan ijtihad mufasir pada tafsir dengan menggunakan sunnah, sementara ijtihad tidak diperlukan pada tafsir nabawi, karena Nabi sendiri telah menetapkan dan memperjelas suatu ayat melalui hadisnya. Sedangkan

${ }^{15}$ Musāad bin Sulaiman bin Nașar al-Ṭayar, "Maṣādir al-Tafsir: al-Tafsir bi al-Sunnah", http://www.attyyar.net/container.php?fun=artview\&id=270 (diakses tanggal 18 Oktober 2016).

${ }^{16}$ Khalid bin 'Abd al-Aziz al-Bātili, Al-Tafsìr al-Nabawi MuqaddimatunTa'siliyy atunMa'aDirāsatin HadìisiyyatinLiAhādìisi al-Tafsìr al-Nabawi al-Ṣarīh, Juz 2, (Riyaḍ: Dār KunuzIsybiliya, 2011), h. 54. 
pada tafsir menggunakan sunnah, seorang mufasir dituntut memiliki daya nalar yang tinggi sehingga dapat menangkap ucapan, perbuatan, dan takrir Nabi SAW meskipun tidak secara tegas menafsirkan suatu ayat, namun dapat digunakan untuk mendukung suatu penafsiran.

Dari definisi al-Tayar, dapat dipahami bahwa istilah tafsir dengan sunnah lebih umum dan mencakup istilah tafsir nabawi. Banyak hadis atau sunnah Nabi SAW menafsirkan ayat al-Qur'an sehingga dikatakan tafsir nabawi. Model tafsir Nabawi ini diacu oleh mufasir ketika mereka menafsirkan ayat yang sama. Akan tetapi, seorang mufasir sering menemukan bahwa banyak ayat tidak diketemukan tafsir nabawinya, dan karena itu mufasir perlu berijtihad untuk mendapatkan penafsiran yang tepat. Dalam proses berijtihad untuk mendapatkan penafsiran yang tepat itu, mufasir perlu mencari ayat al-Qur'an lain untuk menafsirkan ayat pertama, ini disebut dengan menafsirkan alQur'an dengan al-Qur'an. Namun jika tidak diketemukan, mufasir akan mencari ayat al-Qur'an lain atau hadis/sunnah yang dianggap dapat mendukung kebenaran ijtihad penafsirannya. Hadis atau sunnah yang secara langsung tidak menafsirkan ayat, namun digunakan dan dianggap mendukung penafsiran inilah yang disebut dengan istilah tafsir dengan sunnah.

Langkah mufasir menggunakan hadis atau sunnah untuk mendukung hasil ijtihadnya, sejalan dengan hadis Muaż bin Jabal yang diriwayatkan oleh Abu Dawud ketika Nabi mengutusnya untuk suatu tugas di Yaman. Nabi bertanya kepadanya: "Bagaimana engkau menghukumi jika diajukan kepadamu suatu perkara?", Muaż menjawab: "Aku menghukumi menggunakan kitabullah", Nabi bertanya: "Jika jawabannya tidak engkau temukan di Kitabullah?”, Muaż menjawab: "Menggunakan sunnah Rasulullah”. Nabi bertanya: "Jika engkau tidak menemukan jawabannya di Sunnah Rasulullah?”, Muaż menjawab: "Jika aku tidak menemukan jawabannya di dalam Kitabullah dan Sunnah Rasul maka aku akan berijtihad menggunakan pendapatku”. Lalu Rasulullah menepuk dada Muaż dan bersabda: "Segala puji bagi Allah yang telah menepatkan jawaban utusan Rasulullah kepada yang diridai Rasulullah”. 
Berdasarkan hadis di atas dapat kita pahami bahwa metode tafsir bi al-Ma'sur yang menafsirkan ayat al-Qur'an menggunakan ayat alQur'an yang kemudian didukung menggunakan sunnah adalah metode penafsiran yang sudah tepat, baru setelah tidak ditemukan penafsiran dengan al-Qur'an dan Sunnah, seorang mufasir menggunakan metode tafsir bi al-Ra'yi.

Pembedaan istilah menjadi dua: tafsir nabawi dan tafsir menggunakan sunnah, atau digunakan satu istilah saja menjadi tafsir nabawi, tidaklah terlalu prinsip. Sebab kedua perbedaan itu pada hakikatnya adalah satu, yaitu menggunakan sunnah nabi sebagai alat untuk menafsirkan al-Qur'an.

\section{Fungsi Sunnah dalam Penafsiran al-Qur'an}

Secara umum fungsi hadis terhadap al-Qur'an adalah untuk menjelaskan makna yang terkandung dalam al-Qur'an, sebagaimana firman Allah dalam Surah al-Nahl ayat 44,Dan Kami turunkan kepadamu al-Qur'an, agar kamu menerangkan kepada umat manusia apa yang telah diturunkan kepada mereka dan supaya mereka memikirkan".

Imam Malik bin Anas menyebutkan lima macam fungsi, yaitu bayan al-taqrir, bayan al-tafsìr, bayan al-tafșill, bayan al-ba't,dan bayan al-tasyri'. Imam Syafi'i menyebutkan lima fungsi, yaitu bayan al-tafșil, bayan al-tahsișs, bayan al-ta'yin, bayan al-tasyri' dan bayan alnasakh. Dalam "Al-Risalah", ia menambahkan dengan bayan al-ishārah. Sedangkan Imam Ahmad bin Hanbal menyebutkan empat fungsi, yaitu bayan al-ta'kīd, bayan al-tafsir, bayan al-tashri' dan bayan al-takhsiị. ${ }^{17}$

Seorang mufasir ketika menafsirkan al-Qur'an harus memperhatikan fungsi-fungsi ini. ${ }^{18}$ Penjelasan dari bayan-bayan ini adalah sebagai berikut:

${ }^{17}$ Munzier Suparta, Ilmu Hadis..., h. 58, mengutip Hasbi Ash-Shiddieqi, Sejarah dan Pengantar Ilmu Hadis, (Jakarta: Bulan Bintang, 1980), h. 176-188. Lihat juga Abdul Majid Khon, Ulumul Hadis, (Jakarta: Bumi Aksara, 2012), h. 18-24; Idri, Studi Hadis, (Jakarta: Kencana, 2010), h. 25-30; Lihat Nawir Yuslem, Ulumul Hadis, (Jakarta: Mutiara Sumber Widya, 2003), h. 70.

${ }^{18}$ Lihat Khalid Abdul al-Rahman al-Ak, Ușūl al-Tafsir..., h. 128-130; Khalid bin Usman al-Sabit, Qawa'id al-Tafsir: Jam'anwaDirasatan, jilid 1, (Kairo: Dar Ibn 


\section{Bayan al-Taqrir}

Bayan al-taqrirdisebut juga dengan bayan al-ta'kidataubayan alisbät, yaitu menetapkan dan memperkuat apa yang telah diterangkan di dalam al-Qur'an, mengukuhkan apa yang sudah disebutkan dalam al-Qur'an. Contohnya adalah hadis riwayat Muslim yang berbunyi: Apabila kalian melihat hilal (bulan Ramadhan), maka berpuasalah, dan juga jika melihat hilal (bulan Syawal) maka berbukalah". Hadisinimen-taqriratau mengukuhkan surah al-Baqarah ayat 185 berikut: "Maka barang siapa di antara kamu ada yang mempersaksikan bulan, maka berpuasalah". Contoh lain dari bayan taqrirbisa dilihat dalam penetapan hukum wajib shalat, zakat, puasa, haji, pengharaman syirik, saksi palsu, membunuh yang diharamkan, hak-hak dua orang tua, hak dan kewajiban suami istri.

Dalam bayan taqrir diperlukan adanya persesuaian dan kecocokan antara Sunnah dan al-Qur'an. Sunnah datang dengan keterangan atau perintah yang sejalan dengan kandungan al-Qur'an, bahkan persis sama, baik dari segi keumumannnya (mujmāl), maupun perinciannya (tafṣill).Dalamhal ini, sunnah mengukuhkan al-Qur'an, sehingga hukum wajib atau haram berasal dari dua sumber, al-Qur'an sebagai yang menetapkan, dan sunnah pengukuh atas ketetapan itu.

\section{Bayan Tafsir}

Fungsi hadis sebagai bayan tafsir, adalah hadis berfungsi memberikan rincian dan tafsiran terhadap ayat-ayat al-Qur'an yang masih bersifat global (mujmāl), memberikan pembatasan (taqyīd) ayat-ayat al-Qur'an yang bersifat mutlak, dan mengkhususkan ( $t a k h s ̣ i s ̣)$ terhadap ayat-ayat al-Qur'an yang masih bersifat umum. Dengan demikian hadis berfungsi sebagai:

\section{a. Tafșil al-Mujmal}

Tafșilal-mujmālberarti memerinci yang global. Hadis memberikan penjelasan ayat-ayat al-Qur'an yang bersifat global

'Affan, 1421H.), h. 142-148; Muhammad bin 'Abdullah bin 'Ali al-Khadiri, Tafsir alTābi'in: 'Arḍ wa Dirasah Muqaranah, jil.2, (Riyadh: Dar al-Wathan Lin-Nasyr, 1999), h. 630-631. 
secara terperinci, baik yang berkaitan dengan hukum atau ibadah lainnya. Ada yang menyebut bayan ini dengan bayan tafṣilatau bayan tafsir.Dalamhal ini, hadis merinci ayat mujmal yaitu ayat yang dilalahnya masih tersembunyi dari maknanya, dan tidak ada cara lain menyingkirkan yang tersembunyi kecuali menjelaskan yang timbul dari yang ijmal tadi.

Contohnya adalah lafaz shalat di dalam al-Qur'an yang secarabahasa bermakna doa seperti pada Surah al-Taubah ayat 103. ${ }^{19}$ sedangkan pada ayat lain yaitu Surah al-Nisa ayat $103^{20}$ menyebutkanbahwa shalat itu memiliki waktu-waktu tertentu, maka yang dimaksud -shalat pada ayat kedua ini adalah shalat wajib lima waktu. Untuk mengetahui bahwa shalat pada ayat ke dua bermakna shalat fardhu adalah melalui sunnah yang menjelaskan tata cara shalat, syarat dan rukun, hal-hal yang membatalkan, dan termasuk waktuwaktu pelaksanaannya.

Contoh lain, hadis Nabi riwayat Muslim yang memerintahkan "ambillah manasik hajimu dariku".Rincianmanasik haji yang disebutkan dalam banyak hadis adalah penjelas ayat al-Qur'an yang memerintahkan kewajiban ibadah haji.

\section{b. Takhsisal-Am}

Pada bayan ini, hadis memiliki fungsi mentakhsis/ mengkhususkan ayat-ayat al-Qur'an yang bersifat umum. Contohnya adalah ahli waris anak yang mewarisi bapak seperti pada firman Allah Surah al-Nisa' ayat $11^{21}$.Pengertian lahir ayat ini adalah setiap ayah menerima waris, namun nabi mentakhṣis dalam hadisnya kecuali para nabi.Nabi bersabda bahwa: "kami para nabi tidak bisa mewarisi, apa yang kami tinggalkan adalah sedekah”.2 Begitu juga dalam hal disebut

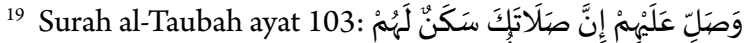

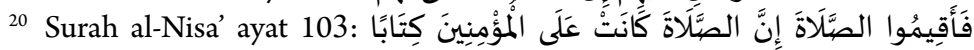
مَوْقُوتًا

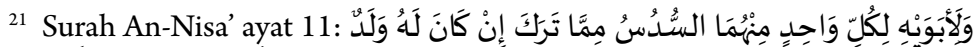

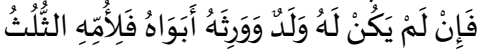

22 Teks hadis riwayat Ahmad sebagai berikut:

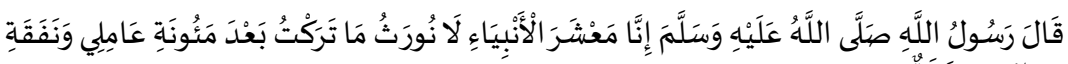


dalam al-Qur'an bahwa setiap anak mewarisi bapaknya, ditakhsis oleh nabi bahwa "pembunuh tidak dapat mewarisi apa pun dari yang dibunuh"23.

\section{c. Taqyid al-Muthlaq}

Pada bayan ini, hadis memiliki fungsi membatasi kemutlakan ayat-ayat al-Qur'an. Maksudnya, keterangan-keterangan yang ada dalam ayat al-Qur'an adalah mutlak, lalu hadis datang mengtaqyidatau membatasi kemutlakan tersebut. Contohnya adalah firman Allah dalam Surah al-Maidah ayat $38^{24}$ yang menjelaskan bahwa pencuri laki dan pencuri perempuan diperintahkan agar dipotong tangan keduanya. Sunnah menunjukkan bahwa pemotongan dilakukan dari pergelangan bukan dari siku-siku atau pundak, ${ }^{25}$ dan pemotongan dilakukan jika barang yang dicuri senilai seperempat dinar ke atas. ${ }^{26}$

\section{Bayan at-Tasyrī'}

Bayan at-Tasyri’ artinya mewujudkan hukum yang belum ada dalam al-Qur'an. Pada bayan at-Tasyrī', hadis memiliki fungsi menciptakan hukum syariat (tasyrí'). Para ulama berbeda pendapat mengenai fungsi sunnah sebagai dalil suatu hukum yang tidak disebutkan dalam al-Qur'an.Mayoritas mereka berpendapat bahwa sunnah berdiri sendiri sebagai dalil hukum, ini bukan berarti mengutamakan Sunnah mengabaikan al-Qur'an, akan tetapi juga

${ }^{23}$ Dalam riwayat Bukhari Nabi bersabda: لا يرث المسلم الكافرولاالكافر المسلم, Teks hadis lain yang diriwayatkan Ad-Darami :

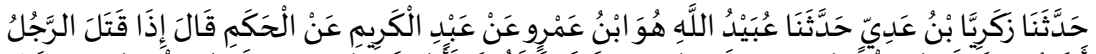

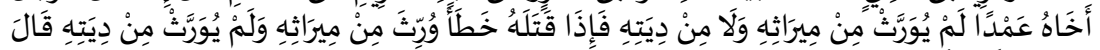

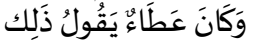

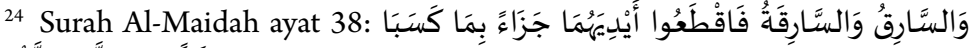

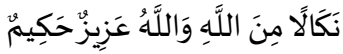

أتى رسول الله صلى الله عليه و سلم بسارق فقطع يده من مفصل : lihat Muhammad bin Isma'il, Subul Al-Salam, Juz IV, (Bandung: Dahlan, t.t.), h. 27.

${ }^{26}$ Hadis yang menjelaskan pemotongan tangan pencuri dilakukan jika barang yang dicuri nilainya lebih dari seperempat dinar adalah riwayat Syaikhani sebagai

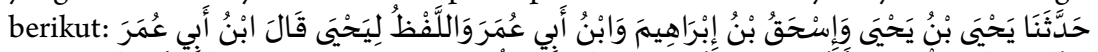

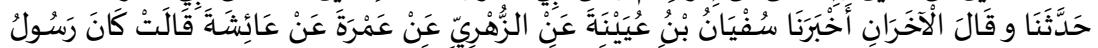

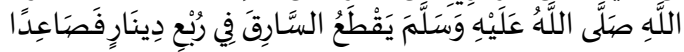


mengikuti petunjuk al-Qur'an untuk taat kepada Allah dan Rasul-Nya. Sementara yang lain berpendapat bahwa sunnah menetapkan dalil yang terkandung atau tersirat secara implisit dalam teks al-Qur'an. ${ }^{27}$

Contohnya adalah Sunnah mengharamkan menikahi wanita bersama bibi dan paman wanitanya, atau haramnya saudara sesusuan seperti haramnya senasab, mewarisinya nenek, larangan saling mewarisi antara Muslim dan kafir, dan anak perempuan dari anak laki-laki mendapatkan bagian satu per enam jika mempunyai anak perempuan. Sunnah juga mengharamkan memakan daging keledai ternak dan setiap binatang berbelalai.

\section{Bayan al-Nasakh}

Al-Nasakh artinya menghapus. Bayan al-Nasakh, adalah hadis yang berfungsi menghapus hukum yang diterangkan dalam al-Qur'an. Mengingat kedudukan hadis menepati posisi kedua setelah al-Qur'an, para ulama berbeda pendapat dalam menerima dan mengakui fungsi hadis yang menasikhatau menghapus sebagian hukum al-Qur'an.

Kata nasakh secara bahasa berarti ibțal (membatalkan), izālah (menghilangkan), tahwīl (memindahkan) dan tagyīr (mengubah). Ulama mutaqaddimin memandang bahwa terjadinya nasakh ini karena adanya dalil syara' yang mengubah suatu ketentuan hukum meskipun jelas, karena telah berakhir masa keberlakuannya serta tidak bisa diamalkan lagi, dan Syari' (Pembuat syariat yakni Allah) menurunkan ayat tersebut temporal dan tidak diberlakukan selamanya. ${ }^{28}$ Ketentuan yang datang kemudian menghapus ketentuan yang datang terdahulu, karena yang terakhir dipandang lebih luas dan lebih cocok dengan nuansanya. Tidak berlakunya suatu hukum melalui cara ini harus mengikuti syarat dan ketentuan "nasakh waal-mansūkh". Hadis sebagai ketentuan yang datang kemudian dapat menasakh ketentuan al-Qur'an yang datang lebih dahulu. Kelompok yang membolehkan nasakh jenis ini adalah golongan Mu'tazilah, Hanafiyah, dan mazhab IbnHazm al-Zahiri. Hanya saja Mu’tazilah membatasi fungsi nasakh ini

27 Abdul Majid Khon, Ulumul Hadis, Jakarta: Amzah, 2012, h. 22. Lihat juga Khalid Abdul al-Rahman al-Ak, Ushul al-Tafsir ..., h. 129.

${ }^{28}$ Munzier Suparta, Ilmu Hadis..., h. 65. 
hanya berlaku untuk hadis-hadis yang mutawatir lafziy saja. Sementara Hanafiah membolehkan hadis masyhur meskipun hadis ahad untuk menasakh sebagian hukum al-Qur'an. Adapun kelompok yang menolak nasakh jenis ini adalah Imam Syafi'i dan sebagian besar pengikutnya, meskipun nasakh tersebut dengan hadis mutawatir. Kelompok lain yang juga menolak adalah sebagian besar pengikut mazhab Zhahiriyah dan kelompok Khawarij. ${ }^{29}$

Contoh hadis yang menasakh al-Qur'an adalah hadis riwayat Bukhari dalam kitab waṣaya (hadis nomor 2542) yang berbunyi: لاوصية لوارث (ahli waris tidak boleh mendapat wasiat). Hadis ini menurut mereka yang membolehkan, adalah menasakh isi firman Allah dalam Surah al-Baqarah ayat 180 :

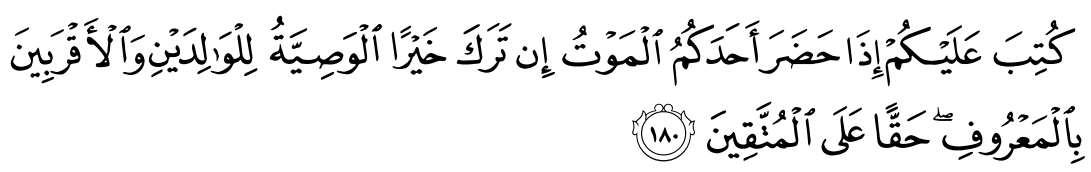

"Diwajibkan atas kamu, apabila seseorang di antara kamu kedatangan (tanda-tanda) kematian, jika ia meninggalkan harta yang banyak, berwasiat untuk ibu bapa dan karib kerabatnya secara ma'ruf (ini adalah) kewajiban atas orang-orang yang bertakwa".

Sementara itu, Khalid Usman al-Sabit menambahkan beberapa fungsi lain dari fungsi hadis terhadap al-Qur'an, yaitu:

1. Mendefinisikan makna yang mubham (samar). Mubhamadalah setiap ayat yang ditunjuk dalam al-Qur'an dengan nama selain nama yang biasa dikenal, misalnya dalam hadis riwayat Tirmiżi bahwa dari Nabi SAW saat menjelaskan Surah al-Isra' ayat 78 Nabi menjelaskan bahwa yang menyaksikan adalah malaikat malam dan malaikat siang ${ }^{30}$. Tirmiżi juga meriwayatkan bahwa Nabi SAW membaca ayat Surah al-Isra' ayat 79, lalu ditanya

${ }^{29}$ Ibid., h. 66. Lihat juga Musthafa al-Siba'i, Al-Sunnah waMakānatuhāfĩ alTasyri' al-Islāmi, h. 360.

${ }^{30}$ Hadis tersebut berbunyi:

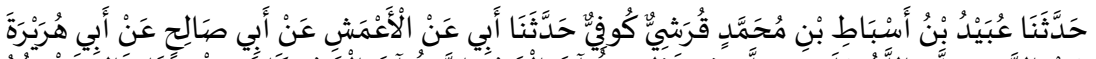

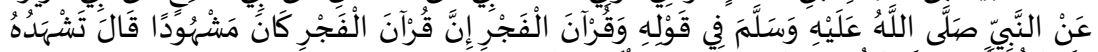

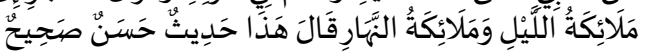


mengenai maksudnya, dan Nabi menjawab bahwa maksud dari ayat itu adalah syafaat. ${ }^{31}$

2. Menjelaskan lafazd. Contohnya lafazdwasațāpada Surah AlBaqarah ayat 143, Nabi SAW menerangkan bahwa maknanya adalah adil. ${ }^{32}$

3. Menjelaskan kisah-kisah, seperti hadis Nabi SAW yang panjang dan terkenal yang menceritakan perihal Nabi Musa dan Nabi Hidir.

\section{E. Metode dan Model Penafsiran Sunnah terhadap al-Qur'an}

Pada bagian awal makalah ini disebutkan bahwa hubungan antara kata tafsir dan sunnah menghasilkan dua istilah, yaitu al-Tafsì al-Nabawi (tafsir nabawi) dan al-Tafsìrbi al-Sunnah (tafsir menggunakan sunnah) seperti yang diterangkan oleh Musa'ad Ibnu Sulaiman bin Nashar al-Tayar ${ }^{33}$. Namun ada juga yang menggabungkan dua istilah itu dengan satu istilah saja yaitu al-Tafsìr al-Nabawiatau tafsir nabawi seperti yang digunakan oleh Khalid bin 'Abd al-Aziz al-Bātili.i. ${ }^{34}$

Pada bagian ini, akan dijelaskan metode dan model penafsiran nabawi dalam arti penafsiran menggunakan sunnah Nabi SAW baik dalam bentuk ucapan, perbuatan maupun taqrir Nabi untuk menjelaskan ayat al-Qur'an, yang dijelaskan oleh beberapa ahli tafsir. ${ }^{35}$

31 Hadis itu berbunyi:

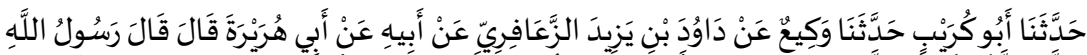

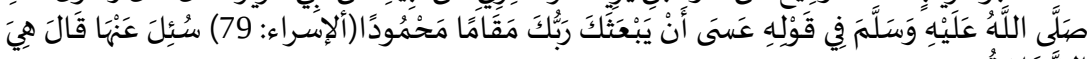

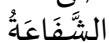

32 Hadis riwayat Bukhari, berbunyi:

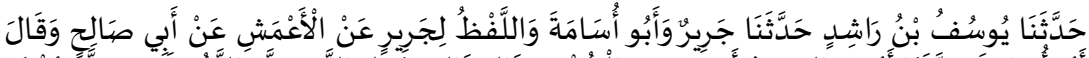

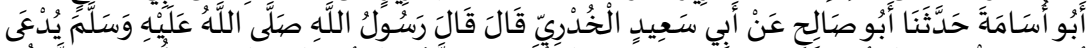

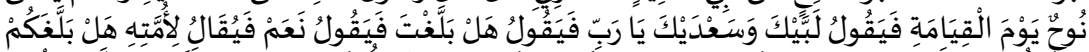

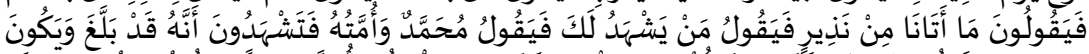

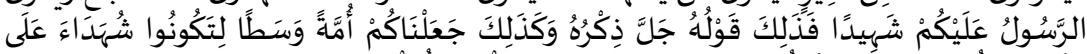

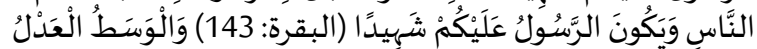

${ }^{33}$ Musāad bin Sulaiman bin Nașar al-Tayar, "Mașadir al-Tafsir...

${ }^{34}$ Khalid bin 'Abd al-Aziz al-Bātili, Al-Tafsir al-Nabawi ..., h. 54.

${ }^{35}$ Lihat Khalid Abdul al-Rahman al-Ak, Ushul al-Tafsir ..., h. 128-130; Khalid bin Usman al-Sabit, Qawa'id al-Tafsir... , h. 130-148; Muhammad Abdurrahman 


\section{Sunnah atau hadis digunakan untuk menjelaskan asbäbal-nuzul dari al-Qur'an}

Tidak ada keraguan bahwa orang yang mengetahui sebab turunnya ayat atau surahal-Qur'an lebih memahami ayat atau surah, sehingga mengetahui penafsiran yang tepat dari ayat atau surah tersebut. Contohnya firman Allah pada Al-Baqarah ayat 198:

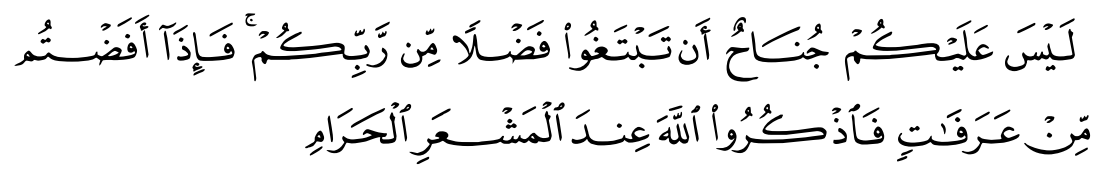

"Tidak ada dosa atasmu mengharapkan fadhl dari Tuhanmu, apabila engkau telah menyelesaikan wuquf di Arafah maka perbanyaklah mengingat Tuhanmu di sisi Al-Masy'aral-Haram".

Apakah yang dimaksud dengan fadhl? Bisa jadi terkandung dzikir, doa, pahala, tetapi makna sebenarnya adalah berdagang pada waktu haji, berdasarkan hadis riwayat Bukhari:

'Usman bin Al-Haytam menyampaikan khabar kepada kami, IbnJuraij memberi khabar kepada kami, 'Amr bin Dinar berkata, Ibn 'Abas r.a., berkata: Dhu Al-Majāz dan 'Ukāz adalah pasar tempat berkumpul manusia pada jaman jahiliyah, tatkala Islam datang para sahabat seolah membenci itu, sehingga diturunkanlah: ayat yang berbunyi"tidak ada dosa bagimu berusaha faḍl dari Tuhanmu dalam musim-musim haji."

\section{Sunnah atau hadis digunakan untuk menjelaskan lafazd atau ayat al-Qur'an}

a) Penjelasan terhadap makna lafaz yang belum diketahui maknanya selain melalui penjelasan $\mathrm{Nabi}$, contohnya hadis riwayat Muslim:

Abu Bakar bin Abi Syaibah menyampaikan hadis kepada kami, dengan lafazd darinya, Ali bin Mushir menyampaikan hadis kepada kami, dari Al-Mukhtar, dari Anas berkata, suatu kali Rasulullah SAW pada suatu hari di depan kita, tiba-tiba tertidur sejenak kemudian mengangkat kepalanya sambil tersenyum, lalu kita bertanya: "Apa yang menyebabkan engkau tertawa ya Rasulullah?". Rasul menjawab: "Baru saja diturunkan kepadaku satu surah, lalu nabi membacakan: "innā a'țaiynā ka al-kauthar fașalli li rabbika wan har innashāniaka huwa

Muhammad, Penafsiran al-Qur'an dalam Perspektif Nabi Muhammad, alih bahasa, Rosihan Anwar, (Bandung: Pustaka Setia, 1992), h. 99-151. 
al-abtar" lalu Nabi bertanya: "apakah kalian tahu apakah al-kauthar itu?". Kami menjawab: "Allah dan Rasul-Nya yang lebih tahu", Nabi bersabda: "itu adalah sungai yang dijanjikan Tuhanku Azza wajalla yang memiliki kebaikan yang banyak, dia adalah telaga yang dikembalikan ke dalamnya umatku pada hari kiamat, wadahnya sejumlah bintangbintang, bergemetar seorang hamba diantara mereka, lalu aku berkata, Ya Tuhan ia adalah umatku, lalu dia berkata: engkau tidak tahu apa yang aku ceritakan setelah kamu

b) Penjelasan terhadap makna lafaz yang diperselisihkan maknanya oleh para sahabat. Contohnya hadis riwayat Ahmad:

Yahya menyampaikan hadis kepada kami, dari Anas bin Abi Yahya berkata, Abi menyampaiakan hadis kepadaku, dia berkata aku mendengar Aba Sa'id berkata, berselisih paham dua orang lelaki dari bani Hudzrah dan seorang laki-laki dari bani 'Amr bin 'Auf mengenai "Al-masjid alladhìussisa 'ala al-taqwa". Al-Huzdri berkata, ia adalah masjid Rasulullah SAW, sedangkan orang 'Amri berkata, dia adalah masjid Quba', lalau kami mendatangi Rasulullah SAW dan menanyakan kepada beliau tentang hal itu, lalau Nabi menjawab: "dia adalah masjid ini, masjid Rasulullah SAW", dan dia berkata "pada masjid Quba terdapat kebaikan yang banyak".

c) Menjelaskan makna yang terkandung dari suatu lafaz. Contohnya hadis riwayat Syaikhani:

"Umar bin Hafs bin Ghiyas menyampaikan hadis kepada kami, ayahku menyampaikan hadis kepadaku, Al-A'masy menyampaikan hadis kepada kami, Muslim menyampaikan hadis kepada kami, dari Masruq dari Aisyah r.a., berkata: "ketika diturunkan ayat akhir surah Al-Baqarah tentang al-riba, Rasulullah SAW membacakannya kepada manusia, lalu Rasul mengharamkan perdagangan khamr".

d) Menjelaskan makna sebenarnya dari apa yang terkandung darisuatu ayat al-Qur'an. Contohnya penjelasan terhadap firman Allah SWT Surah Al-An'am ayat 156:

"Pada hari datang sebagian ayat Tuhanmu, tidak bermanfaat sesorang imannya yang tidak beriman dari sebelumnya, atau berusaha berbuat baik dalam imannya"

Dalam Hadis, Nabi menjelaskan bahwa saat iman yang tidak berguna kecuali kalau seseorang sudah punya iman terlebih dahulu, itu terjadi tatkala matahari terbit dari arah barat:

"Ishāq telah menyampaikan hadis kepadaku, 'Abd al-Razāq menyampaikan khabar kepada kami, Ma'mar menyampaikan khabar kepada kami, dari 
Hammām, dari Abi Hurairahr.a., berkata, Rasulullah SAW bersabda: "Tidak didirikan saat hari kiamat sehingga matahari terbit dari barat, maka apabila matahari terbit dari barat dan manusia melihatnya, mereka semua beriman, pada saat tidak bermanfaat seseorang imannya, kemudian Rasul membaca ayat (al-An'àm ayat 156)".

e) Menjelaskan adanya hubungan antara hadis dengan ayat alQur'an baik dari segi lafaz atau istilah dalam suatu ayat. Contoh bentuk ini adalah hadis Rasul riwayat Bukhari yang menjelaskan makna mafätihu al-ghaybi:

"Ibrahim bin Al-Mudzir menyampaikan hadis kepadaku, Ma'n menyampaikan hadis kepada kami, dia berkata Malik menyampaikan hadis kepadaku, dari Abdilah bin Dinar, dari Ibn Umar r.a., sesungguhnya Rasulullah SAW. bersabda: "Kunci-kunci ghaib ada lima yang tidak dapat mengetahuinya kecuali Allah: seseorang tidak mengetahui apa yang terjadi besok selain Allah, tidak mengetahui yang dikandung di dalam rahim selain Allah, tidak mengetahui kapan hujan datang selain Allah, tidak mengetahui di mana seseorang meninggal dunia, dan tidak mengetahui kapan kiamat terjadi".

Hadis ini baik untuk menafsirkan firman Allah pada Surah Al-An'ām: 59: "Milik Allah kunci-kunci yang ghaib, yang tidak mengetahuinya kecuali Allah. Allah mengetahui apa yang ada di daratan dan lautan, daun yang berjatuhan Allah-pun mengetahuinya, biji-bijian di kegelapan bumi, basah dan kering, semuanya ada di kitab yang jelas".

Contoh lain, misalnya penjelasan makna api neraka dalam firman Allah Surah Al-Baqarah ayat 24:

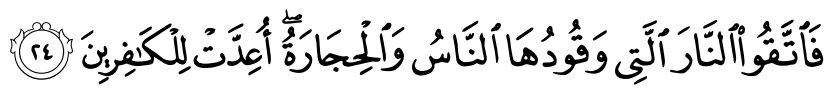

"Takutlah kepada api neraka yang bahan bakarnya adalah manusia dan batu, disediakan untuk orang-orang kafir".

Ayat ini dijelaskan dalam beberapa hadis yang menjelaskan makna dari api neraka, seperti: "Dari Abi Hurairah r.a., bahwasanya Rasulullah SAW bersabda: "Apimu adalah satu bagian dari tujuh puluh bagian api jahannam", dikatakan: "Wahai Rasul kalau seperti itu sudah cukup (panas)" Nabi berkata: "dilebihkan panasnya dengan enam puluh sembilan bagian, setiap bagian sama panasnya". 
Hadis lain menjelaskan: "Dari Abi Hurairahr.a., dari Nabi SAW. bersabda: "Apabila panas matahari sangat terik, maka shalatlah ketika cuaca agak dingin, karena panas yang terik itu dari pancaran jahannam. Api mengadu kepada pelemparnya: "Ya Tuhan sebagianku memakan sebagian yang lain", lalu api itu diizinkan meringankan dua beban, satu beban di musim dingin dan satu beban di musim panas, sebagai keadaan yang kamu rasakan sangat panas, dan keadaan yang engkau rasakan sangat dingin".

Demikian juga hadis yang berbunyi: "Dari Abi Hurairahra., berkata, kita bersama Rasululah SAW, tiba-tiba terdengar suara berdegup, Nabi bersabda: "Tahukah kamu suara apa ini?" Abu Hurairah berkata, kami menjawab: "Allah dan Rasul-Nya yang lebih tahu" Nabi menjawab: "Ini adalah batu yang di lempar ke dalam api neraka selama tujuh puluh tahun dan sekarang sudah sampai di dasar api neraka."

\section{Sunnah atau hadis digunakan untuk menjelaskan topik ayat al- Qur'an, misalnya topik fikih, tasawuf, ilmu pengetahuan alam, sejarah, dll.}

Dalam bidang fikih misalnya, sunnah atau hadis menjelaskan penerapan ayat seperti Surah al-Ṭalāq ayat 1

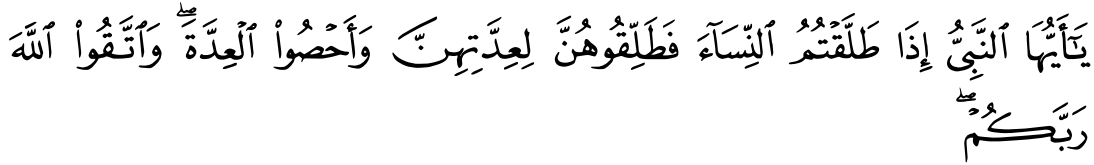

"Wahai Nabi, apabila kamu menceraikan para istri maka ceraikanlah mereka pada masa idah mereka, dan hitunglah masa idah, dan bertakwalah kepada Allah Tuhanmu".

Dalam hadis riwayat Bukhari diceritakan:

"Yahya bin Bukair menyampaikan hadis kepada kami, al-Lais berkata, 'Uqayl menyampaikan hadis kepadaku, dari IbnShihāb dia berkata, Salim memberi khabar kepadaku, bahwasanya 'Abdallah bin 'Umar ra., menyampaikan khabar kepadanya, sesungguhnya dia telah menalak istrinya yang sedang haid, lalu 'Umar menjelaskan hal itu kepada Rasullah SAW, lalu Nabi menjadi marah dan bersabda: "suruhlah ia merujuknya kembali dan menahannya hingga ia suci, lalu haid lagi, lalu suci lagi. Kalau tetap ingin melakukan thalaq, maka ceraikanlah ia 
dalam keadaan suci dan belum disetubuhi, maka itulah idah yang Allah perintahkan"

Untuk topik tasawuf misalnya, Nabi memberikan penjelasan Surah al-Takāंsur ayat 1: أَلَْاكَمُ التَّكَاثُرُ "Telah melupakanmu hidup bermegah-megah".

Nabi bersabda:

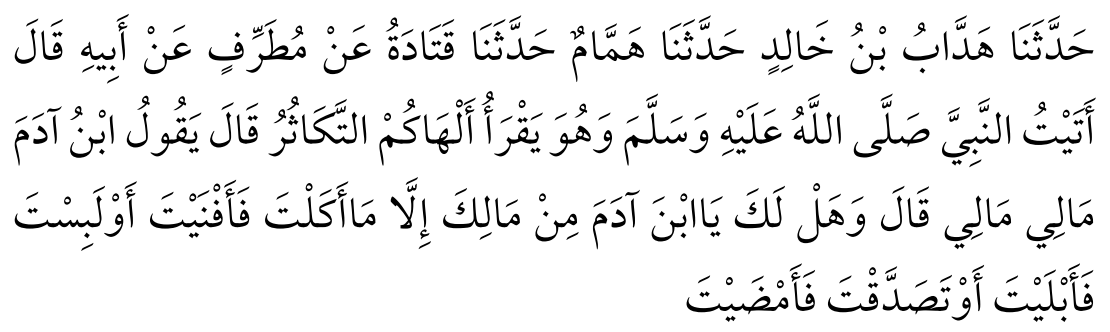

Haddāb bin Khālid menyampaikan hadis kepada kami, Hamām menyampaikan hadis kepada kami, Qatädah menyampaikan hadis kepada kami, dari Mutraf, dari ayahnya berkata, aku mendatangi Nabi SAW beliau membaca "al-hākumual-takātur" Nabi bersabda: "anak Adam berkata: hartaku, hartaku" Nabi bersabda: "Apa yang engkau punya hai anak Adam dari hartamu? Kecuali yang engkau makan lalu habis, yang engkau pakai lalu menjadi lusuh, atau yang engkau sedekahkan lalu berlalu?"

\section{F. Kesimpulan}

Dari paparan tafsir al-Qur'an dengan sunnah, seperti diterangkan di atas dapat diambil kesimpulan bahwa sunnah atau hadis sebagai sumber hukum kedua setelah al-Qur'an memiliki fungsi penting untuk menafsirkan al-Qur'an yaitu sebagai bayānal-taqrīr, bayānal-tafsìryang mencakup tafṣilal-mujmāl, takhṣiṣal-ĀÁm, taqyidalmuṭlaq,jugabāyanal-tasyrī', bāyanal- nasakh dan mendefinisikan yang mubham.Model penggunaan sunnah atau hadis untuk menafsirkan al-Qur'an dapat berbentuk menjelaskan lafazd atau ayat, menjelaskan topik seperti fiqih, tafawuf, sejarah dsb., menjelaskan etimologi, menta'wil, dukungan asbābal-nuzul, dan kegunaan-kegunaan lain yang mungkin saja akan diketemukan seiring dengan perkembangan ilmu pengetahuan. [ ] 


\section{DAFTAR PUSTAKA}

al-Ak, Khalid Abdul al-Rahman, Ushul al-Tafsir wa Qawaiduhu, (Beirut: Dar al-Nakhais, 1986).

al-Bātili, Khalid bin 'Abd al-Aziz, Al-Tafsir al-Nabawi Muqaddimatun Ta'siliyyatun Ma'a Diraasatin Hadiisiyyatin Li Ahādìsi al-Tafsiir al-Nabawi al-Sharīh, Juz 2 (Riyadh: Dar KunuzIsybiliya, 2011).

al-Dzahabi, Muhammad Husain, Al-Tafsīr wa al-Mufassirūn, Jil. 1, (Kuwait: Dar al-Nawadar, 2010).

al-Khadiri, Muhammad bin 'Abdullah bin 'Ali, Tafsir al-Tābi'in: 'Arḍ wa Dirasah Muqaranah, jil.2, (Riyadh: Dar al-Wathan Lin-Nasyr, 1999).

al-Misri, Muhammad bin Mukram bin Manzur al-Afriqi, Lisān al-'Arab, Juz 2, (Beirut: Dar Shadr, t,t.).

al-Qāsimi, Muhammad Jamal al-Din bin Muhammad Sa'id bin Qasim al-Halaq, Qawā'id al-Tahdis min Funūni Muștalah al-Hadis, Juz 1, (Beirut: Dar Al-Kitab Al-Ilmiyyah, t.t.).

al-Sabit, Khalid bin Usman, Qawa'id al-Tafsir: Jam'an wa Dirasatan, jilid 1, (Kairo: Dar Ibn 'Affan, 1421H).

al-Siba'i, Mustafa, Al-Sunnah wa Makānatihā fī al-Tasyri' al-Islāmi, (Kairo: Maktabah Dar al-'Urubah, 1961).

al-Ṭayar, Musāad bin Sulaiman bin Nașar, "Maṣadir al-Tafsir: alTafsir bi al-Sunnah", http://www.attyyar.net/container. php?fun=artview\&id $=270$ (diakses tanggal 18 Oktober 2016).

al-Timisi, Muhammad Mahfudz ibn Abdillah, Manhaj Al-Nazar, (Jeddah: Al-Haramain, 1974).

Ash-Shiddieqi,Hasbi, Sejarah dan Pengantar Ilmu Hadis, (Jakarta: Bulan Bintang, 1980).

Idri, Studi Hadis, (Jakarta: Kencana, 2010) 
Isma'il, Muhammad bin, Subul Al-Salam, Juz IV, (Bandung: Dahlan, t.t.).

Khon, Abdul Majid, Ulumul Hadis, (Jakarta: Bumi Aksara, 2012)

Muhammad, Abdurrahman, Penafsiran al-Qur'an dalam Perspektif Nabi Muhammad, alih bahasa, Rosihan Anwar, (Bandung: Pustaka Setia, 1992).

Munzier Suparta, Ilmu Hadis, (Jakarta: Rajawali Pers, 2011).

Yuslem, Nawir, Ulumul Hadis, (Jakarta: Mutiara Sumber Widya, 2003). 